\title{
THE INFLUENCE OF PRIOR KNOWLEDGE ON STUDENTS' LISTENING AND READING COMPREHENSION
}

\author{
Abdullah Hasan ${ }^{1}$, Rizky Gushendra ${ }^{2}$, Ferry Yonantha ${ }^{3}$ \\ State Islamic University of Sultan Syarif Kasim Riau, Indonesia \\ ('abd_hasanuin@yahoo.com, ${ }^{2}$ ricky82pku@gmail.com, ${ }^{3}$ ferriyonantha@gmail.com)
}

Received: $8^{\text {th }}$ March 2017; Revised: $15^{\text {th }}$ May 2017; Accepted: $22^{\text {th }}$ June 2017

\begin{abstract}
The research aims to investigate the influence of prior knowledge on students' listening and reading comprehension at the tenth year of MAN 1 Pekanbaru. This study is a correlational research that involved 75 respondents as a sample from 150 students of the the tenth year of Science classes as the total population. The respondents were selected by using a simple random sampling technique. 20 items of multiple choice of listening test and 20 items of multiple choice of reading test and 15 items of the prior knowledge questionnaire were used to collect the data. Afterwards, the data were further analyzed by using Pearson product moment correlation for the first and the second hypotheses and MANOVA (Multivariate Analysis of Variance) for the third hypothesis by using SPSS 25. The research findings revealed that the mean score of students' prior knowledge is 73.41 and is categorized as "Good", their listening comprehension is 68.13 and is categorized as "Good", and their reading comprehension is 70.67 and it is also categorized as "Good". It can be seen that the value of Sig. (2-tailed) is $0.000<0.05$. Lastly, for the third hypothesis, the value of significance is $0.000<0.05$. It means Ha is accepted. Then, it is generated that there is a significant influence of prior knowledge on both students' listening comprehension and reading comprehension.
\end{abstract}

Key Words: influence; prior knowledge; listening comprehension; reading

\section{ABSTRAK}

Penelitian ini bertujuan untuk mengetahui pengaruh pengetahuan yang ada pada siswa terhadap pemahaman listening dan speaking siswa kelas X MAN 1 Pekanbaru. Kajian ini merupakan penelitian korelasi yang terdiri dari 75 responden sebagai sampel dari populasi 150 orang siswa kelas X jurusan IPA dengan menggunakan tehnik sampel acak. tes Listening dan Reading menggunakan pilihan ganda yang masing-masingnya terdiri dari 20 soal. Kuesioner digunakan untuk mengumpulkan data. Kuesioner ini terdiri dari 15 pernyataan. Selanjutnya data dianalisa dengan menggunakan korelasi Pearson Product Moment untuk hipotesis yang pertama dan kedua, sedangkan untuk menganalisa hipotesis yang ketiga menggunakan MANOVA (Multivariate Analysis of Variance) SPSS versi 25. Hasil penelitian mengungkapkan nilai rata-rata pengetahuan yang sudah ada adalah 73.41 dan dikategorikan "Baik". Nilai rata-rata listening comprehension 68.13 dan dikategorikan "Baik" serta nilai rata-rata reading comprehension 70.67 dan juga dikategorikan "Baik" Dapat diketahui bahwa nilai signifikan (2;tailed) adalah 0.000<0.05. Akhirnya, untuk hipotesa yang ketiga nilai signifikannya 0.000<0.05. Hasil ini menunjukkan bahwa Ha diterima. Kemudian, disimpulkan bahwa terdapat pengaruh yang signifikan prior knowledge siswa terhadap listening dan reading comprehension.

Kata Kunci: pengaruh; pengetahuan yang sudah ada; pemahaman listening dan reading

How to Cite: Hasan, A. Gushendra, R. Yonantha, F. (2017). The Influence of Prior Knowledge on Students' Listening and Reading Comprehension. IJEE (Indonesian Journal of English Education), 4(1), 1-15. doi:10.15408/ijee.v4i1.4744.

IJEE (Indonesian Journal of English Education), 4 (1), 2017, 1-15

P-ISSN: 2356-1777, E-ISSN: 2443-0390 | DOI: http://dx.doi.org/10.15408/ijee.v4i1.4744

This is an open access article under CC-BY-SA license (https://creativecommons.org/licenses/by-sa/4.0/) 


\section{INTRODUCTION}

In teaching English as a foreign language (TEFL), the teachers or the candidates of teachers should consider the four skills in English (Listening, Speaking, Reading, and Writing) as the achievement to be reached. The achievement in learning English is classified into two major skills: the receptive and the productive skills. Being integrated between the receptive and the productive skills is highly not rebutted. However, understanding and comprehending each major skill deeply is truly needed. Before going too much on discussing about the influence of prior knowledge toward productive skills that seems more interesting or outstanding in communication term, focusing and discussing more deeply on the receptive skills that are the basic skills before gaining the productive skills is much more needed.

Richards and Schmidt (2010) determined the receptive skills consist of listening and reading as the passive skills. It means passive skills because the learners get input or information to process through listening and reading to get an understanding. These skills are really important where the learners get input first and later use the input to produce the output. Normally, all language learners understand language receptively better than they can use productively (Paton \& Wilkins, 2009). Besides, the receptive skills are related to decoding skills (Duquette, 1995). The learners have to receive the messages in the spoken or written form, then transfer them into the brain to be processed, understand and finally comprehend the message. Thus, teaching receptive skills is really important because the learners gain the inputs containing information, messages or ideas and then they process those inputs into the brain to get understanding.

Afterwards, before the learners can use the inputs to produce the outputs, it is better for the learners to obtain the comprehension. It is supported by Haastrup (1991) stating that comprehension precedes production. Understanding the messages is the first requirement before giving any responses to them. Listening comprehension is psychomotor process of receiving sound waves through the ears and transmitting nerve impulses to the brain. (Brown, 2000). It means that listening needs complex ability of analysis not only to listen to what the speaker says, but also to know the meaning of that utterance. Listening comprehension requires the students to listen selectively to what the speaker says, because the information is put in it. In the context of the task, the students must not know all what was 
said, but they must be able to finish all tasks successfully. As what Brown (1994) said, "it does not matter whether or not the students have understood all the details of what was said. All the matter is that the students have been able to construct enough of a reasonable interpretation to make a decent effort at completing the task successfully ( $\mathrm{p}$. $148)^{\prime \prime}$. They can construct the meaning if they can get the main information when they listen and it is much better if they can also get the supporting details of that main idea.

Sadighi and Zare (2006) stated in their survey that learners may face some common problems in listening. They are as follows: (1)Lack of phonological awareness; (2)Lack of vocabulary; (3) Lack of speed; (4) Lack of motivation; (5) Lack of understanding; (6) Lack of associating the prior knowledge with listening materials

Then, reading comprehension is the process of constructing meaning by coordinating a number of complex processes that include word reading, word and world knowledge, and fluency (Harris \& Graham, 2007). According to Anderson (cited in Nunan, 2003), the aim of reading is comprehension. The readers should master the comprehension skill. It requires prior knowledge to have the comprehension skill. The more we have good prior knowledge, the easier we comprehend the reading texts. Dorn and Sofflos (2005) stated that comprehension is a complex process regulated by cognitive, emotional, perceptual, and social experiences. Furthermore, Tankersley (2003) also claimed that comprehension is the central of reading. It is an important one in reading. Without comprehension, the readers are not able to find out the meaning of the text.

Nunan (2003) stated common problems faced by learners in reading as follows: (1) Poor Phonemic Awareness: If the students aren't aware of the sound structure of language and can't recognize and manipulate sounds within words, they need direct phonemic awareness training; Choppy Sounding Out / Unable to Blend Smoothly: If the students 'chop' or segment sounds apart as they sound out, they need instruction so they learn how to smoothly blend sounds together; (3) Improper Directional Tracking: If the students frequently process letters out of order, it indicates they have not developed necessary left to right tracking. Tracking errors are commonly associated with 'whole word' errors. Sometimes the students attempt to sound out, but says sounds out of order; (4) Gaps in direct Knowledge of the Complete Phonemic 
Code: The students need to automatically know the correct sound(s) for the letter(s). Indicators a student is lacking the necessary knowledge of the code include not knowing the sounds in isolation, frequently missing complexities, problems in spelling (major gaps in print=sound relationship), indicators of indirect processing, inability to 'sound out' words. Slow processing can also be an indicator of lack of direct knowledge. If the students process sounds indirectly (such as thinking of another word with the sound) or has to 'think' before they remember sounds, they need practice of the direct print sound knowledge until it is automatic. The knowledge needs to be direct, automatic and complete; (5) Not Paying Attention to Detail: The students need to carefully process all the letters in words. Problems with attention to detail include missing sounds, adding sounds that are not present, missing endings and other details. Accuracy is critical. Help the students learn to process words carefully and pay attention to detail. Stopping students when they miss a word and having them re-read it helps teach careful attention to detail.

Prior knowledge is one of the factors that supports learners' comprehension in listening and reading. Schulman (1999) pointed out that the terms background knowledge and prior knowledge are generally used interchangeably. "Learners construct meaning out of their prior understanding (p. 12)". Any new learning must, in some fashion, connect with what learners already know, learners construct their sense of the world by applying their old understanding to new experiences and ideas".

Prior knowledge is also called as relevant background knowledge, or just plain experience, when students make connections to what they are reading as well as listening, their comprehension increases. Prior knowledge of the learners or also known as the mental schemata is one aspect of language processing which enhances the comprehension in learning a language. Brown (2006) stated that prior knowledge is organized in schemata, generalized mental representations of our experience that are available to help us understand new experience. Therefore, prior knowledge is seen to be important in this research to be investigated whether or not it has influence on students' listening and reading comprehension.

The purpose of this research is to find out the influence of prior knowledge on students' listening and reading comprehension at the tenth 
year of MAN 1 Pekanbaru. Specifically, the study was done to fulfil the objectives that can be stated as follows: (1) To find out the influence of prior knowledge on students' listening comprehension at the tenth year of MAN 1 Pekanbaru; (2) To find out the influence of prior knowledge on students' reading comprehension at the tenth year of MAN 1 Pekanbaru; (3)To find out the influence of prior knowledge on students' listening and reading comprehension at the tenth year of MAN 1 Pekanbaru.

Based on the purpose above, three research questions are formulated: (1) Is there any significant influence of prior knowledge on students' listening comprehension at the tenth year of MAN 1 Pekanbaru?; (2) Is there any significant influence of prior knowledge on students' reading comprehension at the tenth year of MAN 1 Pekanbaru?; (3) Is there any significant influence of prior knowledge on students' listening and reading comprehension at the tenth year of MAN 1 Pekanbaru?

\section{METHOD}

This study is a correlational research which is one of the quantitative researches. This research is aimed at disclosing the influence of prior knowledge on listening and reading comprehension. There are three variables in this research; students' prior knowledge that is symbolized by " $X$ " is as an independent variable and as dependent variables are the students' listening comprehension that is symbolized by "Y1" and reading commprehension is symbolized by "Y2".

Gay and Airasian (2000) stated that a correlational research attempts to determine whether, and to what degree, a relationship exists between two or more variables. The purpose of this research is to determine the influence among variables, in this case the influence of students' prior knowledge toward their listening and reading comprehension or how to use these relationships to rank prediction quantitatively.

This research was conducted at State Islamic Senior High School (MAN) 1 Pekanbaru which is located on Bandeng Street, Marpoyan Damai subdistrict Pekanbaru. The duration of the research was three months, May up to July 2016. The sample of the research consisted of five classes comprised of 75 respondents. The sample of this study used a simple random sampling. Gay and Airasian (2000) stated that the simple random sampling is the process of selecting a sample in such a way that all individuals in the defined population have an equal and independent chance of being selected 
for the sample. The sample of this research is as follows table 1 .

\section{The Technique of Data Collection}

In order to get the data which were needed to support this study, the techniques of data collection are as follows :

\section{Test}

To find out the correlation between students' prior knowledge on their listening and reading comprehension of the first year students at MAN 1 Pekanbaru, the test was administered. It consisted of 20 questions of multiple choice to assess students' listening comprehension and reading comprehension. Every multiple choice item consisted of four options $(a, b, c$, and $\mathrm{d}$ ). Then, the blueprints of listening and reading comprehension tests are as follows.

Table 1. The Sample of the Research

\begin{tabular}{ccll}
\hline No. & Classes & Total Population & Sample (50\%) \\
\hline $\mathbf{1}$ & X Natural Science 1 & 30 & 15 \\
$\mathbf{2}$ & X Natural Science 2 & 30 & 15 \\
$\mathbf{3}$ & X Natural Science 3 & 30 & 15 \\
$\mathbf{4}$ & X Natural Science 4 & 30 & 15 \\
$\mathbf{5}$ & X Natural Science 5 & 30 & 15 \\
& Total & $\mathbf{1 5 0}$ & $\mathbf{7 5}$ \\
\hline
\end{tabular}

Table 2. Blue Print of Listening Comprehension Test

\begin{tabular}{lll}
\hline $\mathbf{N o}$ & Indicators & Item Number \\
\hline $\mathbf{1}$ & Identifying topic & $5,9,12,16$ \\
$\mathbf{2}$ & Identifying communicative purpose & $1,7,14,17$ \\
$\mathbf{3}$ & Distinguishing the supporting details like text organization & $2,8,13,18$ \\
$\mathbf{4}$ & Identifying specific details containing characters & $3,10,11,19$ \\
$\mathbf{5}$ & Making inference & $4,6,15,20$ \\
\hline
\end{tabular}

Table 3. Blue Print of Reading Comprehension Test

\begin{tabular}{llc}
\hline No & Indicators & Item Number \\
\hline $\mathbf{1}$ & Determining main idea. & $1,6,11,16$ \\
$\mathbf{2}$ & Identifying supporting details. & $5,7,12,17$ \\
$\mathbf{3}$ & Identifying the meaning of vocabulary & $3,10,13,18$ \\
$\mathbf{4}$ & Making inferences. & $4,9,14,19$ \\
$\mathbf{5}$ & Identifying reference. & $2,8,15,20$ \\
\hline
\end{tabular}


Table 4. Blue Print of Prior Knowledge Questionnaire

\begin{tabular}{lll}
\hline No & Indicators & Item Number \\
\hline $\mathbf{1}$ & Familiarity on content & $1,3,5,8,9,12,14$. \\
$\mathbf{2}$ & Familiarity on context & $2,4,6,7,10,11,13,15$. \\
\hline
\end{tabular}

\section{Questionnaire}

Questionnaire was used to investigate the use of prior knowledge by the students in reading or listening comprehension. There were 15 items of statements. The respondents may choose 1 for "YES" or agree with the statements or 0 for " $\mathrm{NO}$ " or disagree with the statements.

\section{FINDINGS AND DISCUSSION}

\section{Findings}

\section{Hypothesis 1}

The first analysis was to investigate the first hypothesis (Ha1) of the study which is whether there is a significant influence of prior knowledge on students' listening comprehension at the tenth year of MAN 1 Pekanbaru.

In this study, Ha was chosen for the first hypothesis based on the assumption and some related studies and theories in this study.

$\mathrm{H} \mathrm{a}_{1}$ was accepted if $\mathrm{p}>\mathrm{a}(\mathrm{p}=$ the significant score of students, $\alpha=$ the significant level), and level of significance of 0.05 was also used to compare. The data were correlated by using Pearson Product Moment Correlation (SPSS) in order to investigate whether there was any correlation or not.

The first hypothesis can be proved by statistical analysis using Pearson correlation. It is explained in Table 5.

Then, the mean scores of students' prior knowledge and their listening comprehension were classified in order to determine the category of the students' prior knowledge and listening comprehension. The classification can be seen from the following table 6 .

Table 5. Mean and Standard Deviation of Prior Knowledge and Listening Comprehension

\begin{tabular}{cccc}
\hline Variable & Mean & Standard Deviation & $\mathbf{N}$ \\
\hline Prior Knowledge & 73.41 & 16.645 & 75 \\
ListeningComprehension & 68.13 & 12.487 & 75 \\
\hline
\end{tabular}


Table. 6. The Classification of Students' Score

\begin{tabular}{cc}
\hline Score & Categories \\
\hline $\mathbf{8 0 - 1 0 0}$ & Very Good \\
$66-79$ & Good \\
$56-65$ & Sufficient \\
$40-55$ & Less \\
$30-39$ & Poor \\
\hline
\end{tabular}

Table. 7. The Influence of Prior Knowledge on Students Listening Comprehension at the Tenth Year of MAN 1 Pekanbaru

\begin{tabular}{cccc}
\hline \multirow{4}{*}{ Prior Knowledge } & \multicolumn{3}{c}{ Correlations } \\
& Prior Knowledge & Listening Comprehension \\
& Pearson Correlation & 1 & $.899^{* *}$ \\
& Sig. (2-tailed) & - & .000 \\
Listening Comprehension & N & 75 & 75 \\
& Pearson Correlation & $.899^{* *}$ & 1 \\
& Sig. (2-tailed) & .000 & - \\
& $N$ & 75 & 75 \\
& $* *$ Correlation is significant at the 0.01 level (2-tailed). &
\end{tabular}

\begin{abstract}
Based on Table 6, the mean prior knowledge is 73.41 . It means the students' prior knowledge is categorized as "Good". Meanwhile, the mean score of listening comprehension is 68.13. It means that the students' listening comprehension is categorized as "Good", too. Thus, it can be stated that the level of both students' prior knowledge and their reading comprehension at the tenth year of MAN 1 Pekanbaru is "Good".

In order to determine the data analysis of the influence of prior knowledge on students' listening comprehension, Pearson Product Moment is used and the results can be seen as in Table 7.
\end{abstract}

Table 7 shows that there are 75 respondents for both variables - prior knowledge and listening comprehension. The significant value (2-tailed) is 0.000 . The Pearson correlation is 0.899 .

There are three ways in interpreting the result of the correlation:

The first is by seeing the table of correlation coefficient interpretation (Sugiono, 2011). From the above calculation, the value of Pearson correlation is 0.899 . According to Sugiono (2011), $\mathrm{r}_{\mathrm{xy}}=0.899$ means the influence of prior knowledge on students' listening comprehension is very high. Then, the value of Pearson correlation shows positive correlation. It means that the higher prior 
knowledge students have, the higher their listening comprehension will be.

The second is by comparing the value of Sig. (2-tailed) with the level of significance (0.05). From the table above, it is seen that the value of Sig. (2tailed) is $0.000<0.05$. It reveals that $\mathrm{Ha}$ is accepted or there is a significant influence of prior knowledge on students' listening comprehension.

The next way is by comparing the value of $r_{x y}$ with $r_{\text {table. }}$. The value of $r_{\text {table }}$ is 0.232 at $5 \%$ significant level and 0.302 at $1 \%$ sinificant level $(\mathrm{df}=\mathrm{N}-2)$. It can be written " $0.232<0.899>0.302$ " $\quad\left(\mathrm{H}_{\mathrm{a}}\right.$ is accepted, and $\mathrm{H}_{\mathrm{o}}$ is rejected). In other words, $r_{x y}$ is higher than $r_{\text {table; }}$ then there is a significant influence of prior knowledge on students' listening comprehension.

In conclusion, hypothesis alternative (Ha1) is accepted. So, there is an influence of prior knowledge on students' listening comprehension at the first year of MAN 1 Pekanbaru.

From the result, it is revealed that the students who have good prior knowledge are able to comprehend the listening materials better because prior knowledge provides good experiences to connect and comprehend the new information the listen. Rubin (1990:78) stated, "attending and interpreting is accomplished more effectively when students know when and how to bring to bear their prior knowledge of the world and of foreign language in processing auditory information." Therefore, prior knowledge can really help students' listening comprehension improved.

\section{Hypothesis 2}

The second analysis is to investigate the second hypothesis (Ha2) of the study which is whether there is a significant influence of prior knowledge on students' reading comprehension at the tenth year of MAN 1 Pekanbaru.

In this study, Ha is chosen for the second hypothesis based on the assumption and some related studies and theories in this study.

Ha2 is accepted if $\mathrm{p}>\mathrm{a}(\mathrm{p}=$ the significant score of students, $a=$ the significant level), and level of significance of 0.05 is also used to compare. The data are correlated by using Pearson Product Moment Correlation (SPSS) in order to investigate whether there is any correlation or not.

The second hypothesis can be proved by statistical analysis using Pearson correlation. It is explained in Table 8.

Then, the mean scores of students' prior knowledge and their reading comprehension are classified in order to determine the category of the students' 
prior knowledge and reading knowledge on students' reading comprehension.

Based on the score classification, the mean prior knowledge is 73.41. It means the students' prior knowledge is categorized into "Good". Meanwhile, the mean reading comprehension is 70.67. It means that the students' reading comprehension is categorized into "Good" too. Thus, it can be stated that the level of both students' prior knowledge and their reading comprehension at the first year of MAN 1 Pekanbaru is "Good".

In order to determine the data analysis of the influence of prior comprehension, Pearson Product Moment is used and the results can be seen in Table 8.

Table 9 shows that there are 75 respondents for both variables - prior knowledge and reading comprehension. The significance (2tailed) is 0.000 . The Pearson correlation is 0.899 .

There are three ways in interpreting the result of correlation. The first is by seeing the table of correlation coefficient interpretation (Sugiono, 2011 \& 2006). From the above calculation, the value of Pearson correlation is 0.899 . According to

Table 8. Mean and Standard Deviation of Prior Knowledge and Reading Comprehension

\begin{tabular}{llll}
\hline Variable & Mean & Standard Deviation & N \\
\hline Prior Knowledge & 73.41 & 16.645 & 75 \\
Reading Comprehension & 70.67 & 11.807 & 75 \\
\hline
\end{tabular}

Table 9. The Influence of Prior Knowledge on Students' Reading comprehension at the Tenth Year of MAN 1 Pekanbaru

\begin{tabular}{llll}
\hline Correlations & & & \\
& & Prior Knowledge & Reading comprehension \\
Prior Knowledge & Pearson Correlation & 1 & $.911^{* *}$ \\
& Sig. (2-tailed) & - & .000 \\
\multirow{2}{*}{ Reading comprehension } & N & 75 & 75 \\
& Pearson Correlation & $.911^{* *}$ & 1 \\
& Sig. (2-tailed) & .000 & - \\
& N & 75 & 75 \\
\multirow{2}{*}{$* *$ Correlation is significant at the 0.01 level (2-tailed). } & \\
\hline
\end{tabular}


Sugiono, $\mathrm{r}_{\mathrm{xy}}=0.911$ is between 0.800 -1.00 , that means the influence of prior knowledge on students' reading comprehension is very high. Then, the value of Pearson correlation shows positive correlation. It means that the higher prior knowledge students have, the higher their reading comprehension will be.

The next is by comparing the value of Sig. (2-tailed) with the level of significance(0.05). From the table above, it is seen that the value of Sig. (2-tailed) is $0.000<0.05$. It reveals that $\mathrm{Ha}$ is accepted or there is a significant influence of prior knowledge on students' reading comprehension.

The last is by comparing the value

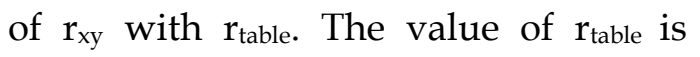
0.232 at $5 \%$ significant level and 0.302 at $1 \%$ sinificant level $(\mathrm{df}=\mathrm{N}-2)$. It can be written " $0.232<0.899>0.302$ " $\left(\mathrm{H}_{\mathrm{a}}\right.$ is accepted, and $\mathrm{H}_{\mathrm{o}}$ is rejected). In other words, $r_{x y}$ is higher than $r_{\text {table, }}$ then there is a significant influence of prior knowledge on students' reading comprehension.

In conclusion, hypothesis alternative (Ha2) is accepted. So, there is a significant influence of prior knowledge on students' reading comprehension at the tenth year of MAN 1 Pekanbaru.
From the result, it is revealed that the students who have good prior knowledge are able to comprehend reading text better because the experiences they had before make them familiar with the content and context of the texts. Brown (2006) stated that prior knowledge is organized in schemata, generalized mental representations of our experience that are available to help us understand new experience. It means students can activate their prior knowledge once the find a familiar materials that they have experienced before. Therefore, prior knowledge can really help students' reading comprehension improve.

\section{Hypothesis 3}

The third analysis is to investigate the third hypothesis (H3) of the study which is whether there is a significant influence of prior knowledge on students' listening and reading comprehension at the tenth year of MAN 1 Pekanbaru.

In this study, Ha is chosen for the last hypothesis based on the assumption and some related studies and theories in this study.

$\mathrm{Ha}_{3}$ is accepted if $\mathrm{p}>\mathrm{a}(\mathrm{p}=$ the significant score of students, $a=$ the significant level), and level of significance of 0.05 is also used to compare. The data are analyzed by 
using MANOVA (Multivariate Analysis of Variance) through SPSS 20 in order to investigate whether there is any influence or not. Further explanation can be seen in Table 10.

Then, to find out whether prior knowledge has significant influence on students' listening and reading comprehension can be investigated by using Multivariate test/MANOVA through SPSS 20. Ha is accepted when the significant value $(p)<$ level of significant 0.05 . Further explanation can be depicted below. Follow table 12.

Table 10. Descriptive Statistics

\begin{tabular}{lllll}
\hline & Prior Knowledge & Mean & Standard Deviation & N \\
\hline Listening & 27 & 40.00 & $\cdot$ & 1 \\
Comprehension & 33 & 40.00 & $\cdot$ & 1 \\
& 47 & 47.86 & 4.880 & 7 \\
& 53 & 56.67 & 5.774 & 3 \\
& 60 & 58.50 & 7.091 & 10 \\
& 67 & 68.33 & 2.887 & 3 \\
& 73 & 67.14 & 6.112 & 14 \\
& 80 & 74.67 & 4.419 & 15 \\
Reading & 76.50 & 7.091 & 10 \\
Comprehension & 80.00 & 3.536 & 5 \\
& 93 & 85.00 & 3.162 & 75 \\
& 100 & 68.13 & 12.487 & 1 \\
& Total & 45.00 & $\cdot$ & 7 \\
& 27 & 45.00 &. & 3 \\
& 47 & 55.71 & 8.381 & 10 \\
& 53 & 56.67 & 7.638 & 3 \\
& 60 & 60.50 & 4.378 & 14 \\
& 67 & 68.33 & 2.887 & 15 \\
& 73 & 68.57 & 5.345 & 10 \\
& 80 & 76.00 & 3.873 & 5 \\
& 87 & 77.50 & 4.249 & 6 \\
& 93 & 84.00 & 2.236 & 75 \\
\hline
\end{tabular}

Table 11. Levene's Test of Equality of Error Variances

\begin{tabular}{lllll}
\hline & F & df1 & df2 & Sig. \\
\hline Listening comprehension & 1.031 & 10 & 64 & .429 \\
Reading comprehension & 2.148 & 10 & 64 & .053 \\
\hline
\end{tabular}


Table 12 The Influence of Prior Knowledge on Students' Listening and Reading Comprehension

\begin{tabular}{|c|c|c|c|c|c|c|c|c|}
\hline Effect & & Value & 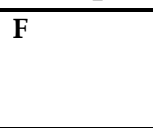 & $\begin{array}{l}\text { Hypoth } \\
\text { esis df }\end{array}$ & Error $\mathrm{df}$ & Sig. & $\begin{array}{l}\text { Noncent. } \\
\text { Parameter }\end{array}$ & $\begin{array}{l}\text { Obser } \\
\text { ved } \\
\text { Power }^{\mathrm{d}}\end{array}$ \\
\hline Intercep & Pillai's Trace & .993 & $4576.839 \mathrm{~b}$ & 2.000 & 63.000 & .000 & 9153.677 & 1.000 \\
\hline \multirow[t]{3}{*}{$\mathbf{t}$} & Wilks' Lambda & .007 & $4576.839 \mathrm{~b}$ & 2.000 & 63.000 & .000 & 9153.677 & 1.000 \\
\hline & $\begin{array}{l}\text { Hotelling's } \\
\text { Trace }\end{array}$ & 145.296 & $4576.839 \mathrm{~b}$ & 2.000 & 63.000 & .000 & 9153.677 & 1.000 \\
\hline & $\begin{array}{l}\text { Roy's Largest } \\
\text { Root }\end{array}$ & 145.296 & $4576.839 \mathrm{~b}$ & 2.000 & 63.000 & .000 & 9153.677 & 1.000 \\
\hline \multirow{4}{*}{$\begin{array}{l}\text { Prior } \\
\text { Knowle } \\
\text { dge }\end{array}$} & Pillai's Trace & 1.014 & 6.587 & 20.000 & 128.000 & .000 & 131.742 & 1.000 \\
\hline & Wilks' Lambda & .088 & $14.898^{\mathrm{b}}$ & 20.000 & 126.000 & .000 & 297.963 & 1.000 \\
\hline & $\begin{array}{l}\text { Hotelling's } \\
\text { Trace }\end{array}$ & 9.159 & 28.392 & 20.000 & 124.000 & .000 & 567.837 & 1.000 \\
\hline & $\begin{array}{l}\text { Roy's } \\
\text { Root }\end{array}$ & 9.030 & $57.791^{\mathrm{c}}$ & 10.000 & 64.000 & .000 & 577.911 & 1.000 \\
\hline
\end{tabular}

a. Design: Intercept + Prior Knowledge

b. Exact statistic

c. The statistic is an upper bound on F that yields a lower bound on the significance level.

d. Computed using alpha $=.05$

To determine whether the students' listening and reading independent variable has significance comprehension at the tenth year of on dependent variable(s) or not, the significant value $(p)$ of 4 different Multivariate tests (Pillai's Trace, Wilks' Lambda, Hotteling's Trace, and Roy's Largest Root) is used to compare with level of significant 0.05 . If significant value $<0.05$, Ha is accepted while Ho and rejected. It means that there is a significant influence of independent variable on dependent variable(s). Afterwards, from Table 12 above, it is seen that the significant value of 4 different Multivariate tests is $0.000<$ 0.05 . It reveals that $\mathrm{Ha}$ is accepted or in other words, there is a significant influence of prior knowledge on MAN 1 Pekanbaru.

\section{DISCUSSION}

Mastering listening and reading as receptive skills is very important as input to produce the output. Listening is as an essential skill that should be completed with comprehension. Chastain (1998) defined listening comprehension as the ability to understand speech of native speakers at normal speed in listening situation.

Not only listening, reading also plays an important role in learning. In reading, a reader is actively responsible 
for making sense of text. It is a complex skill to construct the meaning of the text. Pertaining to idea above, Hudelson in Henle \& Henle (2001, p. 154) stated, "An individual construct meaning through a transaction with written text that has been created by the reader's past experiences, language background and cultural framework, as well as the reader's purpose for reading".

How to gain comprehension in listening and reading? Prior knowledge is one of the factors that supports learners' comprehension in listening and reading. According to Schulman (1999), the terms background knowledge and prior knowledge are generally used interchangeably. "Learners construct meaning out of their prior understanding. Any new learning must, in some fashion, connect with what learners already know, learners construct their sense of the world by applying their old understanding to new experiences and ideas (p. 12)".

Prior knowledge is also called as a relevant background knowledge, or just plain experience, when students make connections to what they are reading as well as listening, their comprehension increases. Prior knowledge of the learners or also known as the mental schemata is one aspect of language processes which enhances the comprehension in learning a language. Brown (2006) stated that prior knowledge is organized in schemata, generalized mental representations of our experience that are available to help us understand new experience.

\section{CONCLUSION AND SUGGESTION}

Considering the theories above, this research was carried out mainly to investigate the influence of prior knowledge on students' listening and reading comprehension. Then, specifically, this research study was also done to prove and investigate three different hypotheses. Referring to the research findings, it can be concluded that there is a significant influence of prior knowledge on students' listening and reading comprehension at the tenth year of MAN 1 Pekanbaru.

To conclude, it is suggested to the teachers and practitioners to revisit the concept of prior knowledge which really gives an influence toward students' listening and reading comprehension. The teachers also make efforts how to improve the students to be more active, creative and effective in teaching and learning process in order to achieve the teaching goal. 


\section{REFERENCES}

Brown, H. D. (2000). An interactive approach to language pedagogy. San Fransisco: Longman.

Brown, S. (2006). Teaching listening. Cambridge: Cambridge University Press.

Chastain, K. (1988). Developing second language skills: Theory and practice (3rd ed.) San Diego: Harcourt Brace Jovanovich.

Dorn, L. J., \& Sofflos, C. (2005). Teaching for deep comprehension: A reading workshop approach. Portland: Stenhouse. http://library.nu/ (accessed October 01, 2011).

Duquette, G. (1995). Second language practice: Classroom strategies for developing communicative competence. London: Cromwell Press Ltd.

Gay \& Airasian, P. (2000). Educational research competencies for analysis and application $\left(6^{\text {th }}\right.$ ed.). New Jersey: Pearson Education.

Harris, K. R., \& Graham, S. (2007). Teaching reading to students with learning difficulties. New York: The Guildfoed Press.

Nunan, D. (2003). Practical English language teaching. Newyork: McGraw Hill Company.
Paton, A., \& Wilkins, M. (2009). Teaching adult ESOL principles and practice. New York: Institute of Education.

Richards, J. C., \& Schmidt, R. (2010). Longman dictionary of language teaching and applied linguistics. London: Pearson Education Limited.

Rubin, J. (1990). Improving foreign language listening comprehension. In James E. Alatis (Ed.). Linguistics, language teaching, and language acquisition: The interdependence of theory, practice and research. Gorgetown: Gorgertown University Press.

Schulman, L. (1999). Taking learning seriously",.Change Journal, 31(4), , p. 12, http://www.guide linesonlearning.com/guideline-five (Retrieved on April 27th2013).

Sadighi, F., \& Zare, S. (2006). Is listening comprehension influenced by background knowledge of the learners: A case study of Iranian EFL learners'. The Linguistics Journal, 1(3) Shiraz University of Iran.

Tankersley, K. (2003). The threads of reading strategies for literacy development. Virginia: ASCD. http://library.nu/ (retrieved on October 14, 2011). 